\title{
橋脚まわりの局所洗掘推定のための実用的数值 シミュレーションの開発
}

\section{福岡捷二*・富田邦裕 ${ }^{* *}$. 堀田哲夫*** . 宮川朝浩*}

河道に設置される橋脚が下流の流路や構造物に及ぼす影響を検討することを最終目的 として, 橋脚まわりの局所洗掘深の定量化を数值シミュレーションによって検討した. 流れの計算は福岡らの三次元モデルを改良することにより, 河床変動の計算は流砂運動 の非平衡性を適切に考慮することにより, 橋脚まわりの三次元数値シミュレーションモ デルを構築した。 そして,このモデルを用いた計算結果は, 大型水理模型を用いた局所 洗掘の実験結果を実用的に十分な精度で説明し得ることを示した.

Key Words : bridge pier, local scour, numerical simulation, non-equilibrium sediment transport, hydraulic model test

\section{1.はじめに}

河道内に設置される橋脚は, 河床低下やその周辺の洗 掘によって変形, 転倒などの被害がもたらされている例 が少なくない. 近年の橋梁の大型化や渡河する橋脚数の 増大に伴って橋脚が流れや河床変動に与える影響は大き なものとなってきている．橋脚周辺の洗掘については従 来から数多くの調査研究が行われている(1) 3). 橋脚のま わりの局所洗掘機構については中川・鈴木+1)や宇民到に より詳細に調べられている．最終洗掘深についても多く の予測式が提案されている.この中から適切な推定式を 用いることにより，実際的に有効な精度をもって最終洗 掘深を推定できるようになってきている．実用性の面か らの最大洗掘深に関する我が国の代表的研究としては, 建設省土木研究所 ${ }^{6}$ における橋脚の大型模型実験の成果 がある.これによれば(最大洗掘深)／(橋脚幅）はフルー ド数, (平均水深) /(河床材料の平均粒径) で表現され, 広い範囲の条件に対し最大洗掘深の推定図を与えてい る.しかしながら，橋脚が直接的に下流の流路や構造物 に影響を与える場合には，橋脚のまわりの局所洗掘だけ でなく，橋脚がその上・下流の流況や河床変動に与える 影響も含めた検討が必要となる。このような影響を評価 する場合，現在のところ模型実験が唯一の信頼できる推 定方法である. しかし，模型実験は費用，労力，時間の 面から検討条件の制約を受けざるを得ず，場合によって は模型実験は最善の方法とはなりえない. 最近, Nils ら は, 円柱周りの洗掘について一般曲線座標系を用いた $\mathrm{N}-\mathrm{S}$ 方程式と，レイノルズ応力項を解くために $k^{-} \varepsilon$ モ

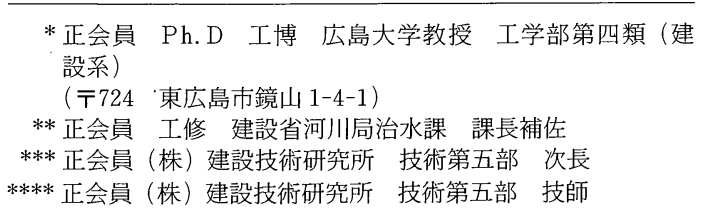

デルを用いて三次元計算を行っている. 彼等は, 洗掘の パターンについてはある程度説明し得ているが，橋脚の まわりの洗掘現象, 最大洗掘深など未だ解けていない. しかし，橋脚まわりの洗掘について精度の高い数值シ ミュレーションが可能となれば, 模型実験と数值シミュ レーションは互いに補完し合い, 橋脚が設置された河道 の河床変動を比較的容易にかつ精度よく推定することが 可能となる. したがって, まず局所洗掘を推定するため の適切な二次元河床変動計算法を開発することが重要な 課題である.

構造物が設置された実河川において用いられている河 床変動の計算法に福岡ら ${ }^{81}$ の方法がある. 福岡らは三次 元の流況計算および河床変動計算をもとに, 水制工のま わりおよびその上，下流の河床変動を計算し，これを用 いて水制工の配置法を見出している．道上・檜谷 ${ }^{9}$ (は鉛 直方向の非静水圧分布を考慮した水制まわりの二次元河 床変動計算手法を提案している.これらの研究は，河川 構造物のまわりの河床変動についても数値計算がかなり 有力な手法になり得ることを示すものである.このよう な実河川や構造物周辺の河床変動に関する数值計算法の 現況を踏まえて本研究では橋脚周辺の流況及び局所洗掘 を数值計算を用いて推定しようとするものである ${ }^{10)}$. こ こでは, 実河川での橋脚周辺の流況, 河床変動を推定す ることを目的として, 福岡らの数值解析手法をもとに浮 遊砂を取り込みさらに橋脚周辺の非平衡掃流砂運動およ び河床面からの浮上量を考慮した数值計算モデルに改良 している. そして，この数値計算結果を大型水理模型実 験による橋脚の局所洗掘深結果と比較検討し, 実用的な 橋脚まわりの局所洗掘深推定法を提案している.

\section{2. 解析の枠組み}

橋脚周辺の局所洗掘は，3 次元的挙動を示す局所流や それにより生じる非平衡性の強い流砂運動により生じる 
ものである. 局所洗掘現象を記述するモデルを構築する にあたっては，現象を支配する物理機構を十分考慮に入 れる必要がある．ここでは宇民5)の研究をもとに橋脚周 辺の洗掘機構について概観する. 橋脚周辺の洗掘は, 橋 脚の直前面と背後でその状況が大きく異なることが特徴 である．前面では鉛直方向に圧力勾配が生じかなり強い 下降流が生まれ，橋脚まわりの河床付近には馬蹄型渦が 発生する. これらにより砂砅は洗掘, 巻き上げられる. 側面では馬蹄型渦，下降流により加速された河床付近の 流れにより洗掘が起こるとともに砂碩は下流へ運ばれ る. 橋脚の背後では剝離流れとなり大きな渦が周期的に 流下する.この渦により砂砅は巻き上げられ下流へ運ば れるが，馬蹄型渦などによる橋脚背後への砂磁の流入量 と巻き上げられ流下する砂碩の量との差から洗掘・堆積 が規定される.こうして進行する局所洗掘は流れを洗掘 孔へ集中させ，そこでの局所流は逆に河床形状により規 定されることになる.

このように橋脚周辺の局所洗掘は, 複雑であり, 特に 橋脚背後の流れの剝離はそれ自身大変大きな問題であ る.このことは, 流れについては, 局所流を厳密に解か なくても洗掘を引き起こす主要な機構がモデルに考慮さ れていれば，橋脚のまわりの洗掘・堆積現象は実用的な 精度で記述できると考えられる.これは局所流が河床形 状に強く規定されるため, 洗掘・堆積現象を適切に表現 することにより橋脚背後を含む流れの解の不完全さはそ れ程重要でなくなるからである，本研究では，このよう な基本的立場から流れと河床変動計算のモデルとして, 実河川の河床変動をよく表現する福岡ら ${ }^{11), 12)}$ の計算モデ ルを用い，これを橋脚まわりの局所洗掘現象を表現でき るモデルに改良する．このモデルでは鉛直流速は小さい と仮定し，無視されたが，橋脚周辺ではこれを無視でき ない.このため圧力分布は, 非静水圧分布として解析す ることが望ましいが，計算の簡便性を重視して静水圧分 布を仮定している. また, 主流速, 二次流速の鉛直分布 は簡単な形で近似されている．このため橋脚背後の剝離 流れを必ずしも十分に表現し得ていないが, 流砂運動の 特徴を十分取り込むことによりこれを補い，工学的に意 味のある解を得ることを目指す. 河床変動については, 砂が浮遊状態で移動することから浮遊砂を考慮する.さ らに，橋脚まわりでは局所的な縦横断勾配が大きく，ま た空間的に流れが加速・減速することから, 流砂運動は その場の流れのせん断力で決まるものではなく上流から の流れの履歴を受け非平衡性を呈することになる．した がって, 河床変動モデルでは三次元の浮遊砂分布および 河床の局所的な縦横断勾配の影響を考慮した平衡流砂量 式を取り込み, さらに掃流砂および砂の浮上量に非平衡 性を考慮している.

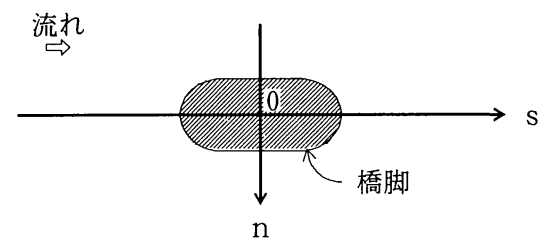

図一1＼cjkstart直交曲線座標と橋脚の関係

\section{3. 橋脚周辺の流況計算}

\section{（1）流れの基礎方程式}

前節で述べた基本的考えに基づいて流れの解析を行 う。基礎方程式は，橋脚形状を近似でき，また実河道へ の適用を考慮して図一1 に示すような直交曲線座標 $s$, $n, z$ を用いて表現する。基礎方程式は，式（1)，（2） および（3）で表される流れの連続式及び鉛直方向に静 水圧分布を仮定した三次元運動方程式である.

$$
\begin{aligned}
& \frac{\partial u}{\partial s}+\frac{1}{r} \frac{\partial(r v)}{\partial n}+\frac{\partial w}{\partial z}=0 \\
& u \frac{\partial u}{\partial s}+v \frac{\partial u}{\partial n}+w \frac{\partial u}{\partial z}+\frac{u v}{r} \\
& =-g \frac{\partial H}{\partial s}+\frac{\partial}{\partial s}\left[\varepsilon \frac{\partial u}{\partial s}\right]+\frac{\partial}{\partial n}\left[\varepsilon \frac{\partial u}{\partial n}\right]+\frac{\partial}{\partial z}\left[\varepsilon \frac{\partial u}{\partial z}\right] \\
& u \frac{\partial v}{\partial s}+v \frac{\partial v}{\partial n}+w \frac{\partial v}{\partial z}-\frac{u^{2}}{r} \\
& =-g \frac{\partial H}{\partial n}+\frac{\partial}{\partial s}\left[\varepsilon \frac{\partial v}{\partial s}\right]+\frac{\partial}{\partial n}\left[\varepsilon \frac{\partial v}{\partial n}\right]+\frac{\partial}{\partial z}\left[\varepsilon \frac{\partial v}{\partial z}\right]
\end{aligned}
$$

ここに, $u, v, w$ はそれぞれ $s, n, z$ 軸方向の流速成 分, $H$ は水位, $r$ は曲率半径, $g$ は重力加速度, $\varepsilon$ は渦 動粘性係数で次式で与えられる.

$\varepsilon=\kappa u_{*} h / 6$

ここに， $u_{*}$ は摩擦速度， $h$ は局所水深， $\kappa$ はカルマン定 数 $(=0.4)$ である.

運動方程式を解く場合には，計算の簡便さを考え，流 速 $u, v$ は，水深方向の分布を式（5）のとおり余弦関 数の合成で表す. 鉛直方向の流速 $w$ は正弦関数の合成 で表し流速振幅 $w_{i}$ は $u_{i}, v_{i}$ より求める.

$$
\begin{aligned}
& u(s, n, z)=\sum_{i=0}^{4} u_{i}(s, n) \cos i \pi z^{\prime} \\
& v(s, n, z)=\sum_{i=0}^{4} v_{i}(s, n) \cos i \pi z^{\prime} \\
& w(s, n, z)=\sum_{i=0}^{4} w_{i}(s, n) \sin i \pi z^{\prime} \\
& \text { ただし }, z_{0} \text { を河床の高さとして, } \\
& z^{\prime}=\left(z-z_{0}\right) / h
\end{aligned}
$$

である。

流速振幅は, 橋脚周辺の流れの複雑さを表現するため 
5 項まで与える.

運動方程式は重み関数を $\cos l \pi z^{\prime} \quad(l=0,1,2,3,4)$ としてガラーキン法によりせん断力を境界条件として河 床汃水面まで積分し離散化する.式（6)，（7）は, $s$ 軸及び $n$ 軸方向の運動方程式を離散化し得られたもの である。

$$
\begin{aligned}
& {\left[\frac{1}{h}\left(\frac{\partial h u_{0}^{2}}{\partial s}+\frac{\partial h u_{0} v_{0}}{\partial n}\right)+\frac{2 u_{0} v_{0}}{r}\right] \int_{0}^{1} \cos l \pi z^{\prime} d z^{\prime}} \\
& +\left[\frac{1}{h}\left(2 \frac{\partial h u_{0} u_{i}}{\partial s}+\frac{\partial h u_{0} v_{i}}{\partial n}+\frac{\partial h u_{i} v_{0}}{\partial n}\right)\right. \\
& \left.+\frac{2}{r}\left(u_{0} v_{i}+u_{i} v_{0}\right)\right] \int_{0}^{1} \cos i \pi z^{\prime} \cos l \pi z^{\prime} d z^{\prime} \\
& +\left[\frac{1}{h}\left(\frac{\partial h u_{i} u_{j}}{\partial s}+\frac{\partial h u_{i} v_{j}}{\partial n}\right)+\frac{2 u_{i} v_{j}}{r}\right] \\
& \times \int_{0}^{1} \cos i \pi z^{\prime} \cos j \pi z^{\prime} \cos l \pi z^{\prime} d z^{\prime} \\
& +\frac{l \pi u_{0} w_{i}}{h} \int_{0}^{1} \sin i \pi z^{\prime} \sin l \pi z^{\prime} d z^{\prime} \\
& +\frac{l \pi u_{i} w_{j}}{h} \int_{0}^{1} \cos i \pi z^{\prime} \sin j \pi z^{\prime} \sin l \pi z^{\prime} d z^{\prime} \\
& =-g \frac{\partial H}{\partial s} \int_{0}^{1} \cos l \pi z^{\prime} d z^{\prime}-\frac{\tau_{s 0}}{\rho h} \\
& -\frac{l^{2} \pi^{2} \varepsilon u_{i}}{h^{2}} \int_{0}^{1} \cos i \pi z^{\prime} \cos l \pi z^{\prime} d z^{\prime} \\
& +\frac{1}{h}\left[\frac{\partial}{\partial s}\left(h \varepsilon \frac{\partial u_{0}}{\partial s}\right)+\frac{\partial}{\partial n}\left(h \varepsilon \frac{\partial u_{0}}{\partial n}\right)\right] \\
& \times \int_{0}^{1} \cos l \pi z^{\prime} d z^{\prime} \\
& +\frac{1}{h}\left[\frac{\partial}{\partial s}\left(h \varepsilon \frac{\partial u_{i}}{\partial s}\right)+\frac{\partial}{\partial n}\left(h \varepsilon \frac{\partial u_{i}}{\partial n}\right)\right] \\
& \times \int_{0}^{1} \cos i \pi z^{\prime} \cos l \pi z^{\prime} d z^{\prime}
\end{aligned}
$$

$\left[\frac{1}{h}\left(\frac{\partial h u_{0} v_{0}}{\partial s}+\frac{\partial h v_{0}^{2}}{\partial n}\right)-\frac{u_{0}^{2}-v_{0}^{2}}{r}\right] \int_{0}^{1} \cos l \pi z^{\prime} d z^{\prime}$

$+\left[\frac{1}{h}\left(\frac{\partial h u_{0} v_{i}}{\partial s}+\frac{\partial h u_{i} v_{0}}{\partial s}+2 \frac{\partial h v_{0} v_{i}}{\partial n}\right)\right.$

$\left.-\frac{2}{r}\left(u_{0} u_{i}-v_{0} v_{i}\right)\right] \int_{0}^{1} \cos i \pi z^{\prime} \cos l \pi z^{\prime} d z^{\prime}$

$+\left[\frac{1}{h}\left(\frac{\partial h u_{i} v_{j}}{\partial s}+\frac{\partial h v_{i} v_{j}}{\partial n}-\frac{u_{i} u_{j}-v_{i} v_{j}}{r}\right)\right]$

$\times \int_{0}^{1} \cos i \pi z^{\prime} \cos j \pi z^{\prime} \cos l \pi z^{\prime} d z^{\prime}$

$+\frac{l \pi v_{0} w_{i}}{h} \int_{0}^{1} \sin i \pi z^{\prime} \sin l \pi z^{\prime} d z^{\prime}$

$+\frac{l \pi v_{i} w_{j}}{h} \int_{0}^{1} \cos i \pi z^{\prime} \sin j \pi z^{\prime} \sin l \pi z^{\prime} d z^{\prime}$

$=-g \frac{\partial H}{\partial n} \int_{0}^{1} \cos l \pi z^{\prime} d z^{\prime}-\frac{\tau_{n 0}}{\rho h}$

$-\frac{l^{2} \pi^{2} \varepsilon v_{i}}{h^{2}} \int_{0}^{1} \cos i \pi z^{\prime} \cos l \pi z^{\prime} d z^{\prime}$
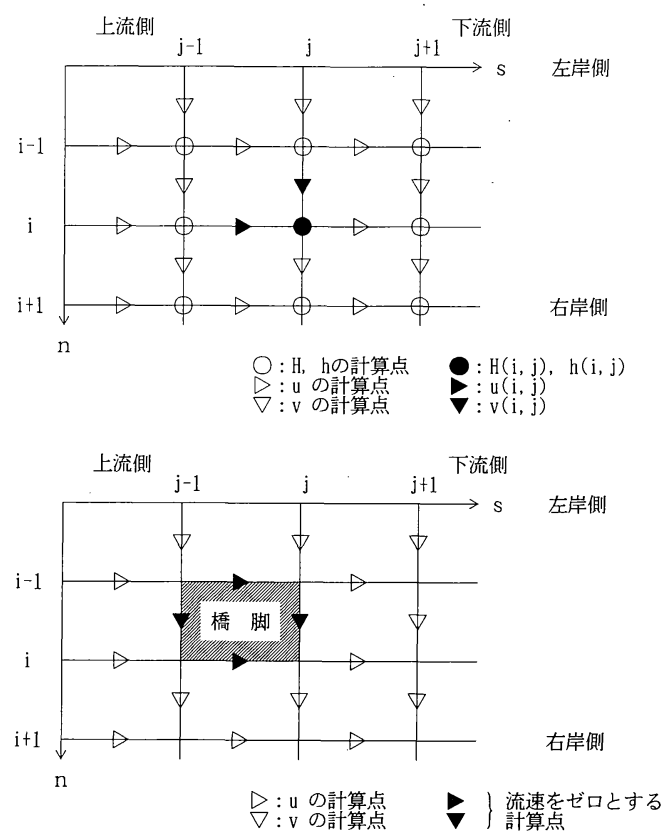

図一2 計算点の配置及び橋脚部における流速計算点の取り扱い

$+\frac{1}{h}\left[\frac{\partial}{\partial s}\left(h \varepsilon \frac{\partial v_{0}}{\partial s}\right)+\frac{\partial}{\partial n}\left(h \varepsilon \frac{\partial v_{0}}{\partial n}\right)\right]$

$\times \int_{0}^{1} \cos l \pi z^{\prime} d z^{\prime}$

$+\frac{1}{h}\left[\frac{\partial}{\partial s}\left(h \varepsilon \frac{\partial v_{i}}{\partial s}\right)+\frac{\partial}{\partial n}\left(h \varepsilon \frac{\partial v_{i}}{\partial n}\right)\right]$

$\times \int_{0}^{1} \cos i \pi z^{\prime} \cos l \pi z^{\prime} d z^{\prime}$

ここに, $i, j$ は式 $(5)$ に示した余弦関数あるいは正 弦関数の組み合わせ, $l$ は重み関数の重み, $\tau_{s 0}, \tau_{n 0}$ は $s$, $n$ 軸方向の河床せん断力である.

境界条件は上流端で流量, 下流端で水位を与え, 河床 では次式のせん断力で規定する.

$$
\left.\begin{array}{l}
\tau_{s 0} / \rho=C_{B} u_{b}\left(u_{b}^{2}+v_{b}^{2}\right)^{1 / 2} \\
\tau_{n 0} / \rho=C_{B} v_{b}\left(u_{b}^{2}+v_{b}^{2}\right)^{1 / 2}
\end{array}\right\}
$$

ここに $u_{b}, v_{b}$ は基本式を解いて求められる河床での スリップ速度, $C_{B}$ は河床の摩擦係数であり粗度係数 $n_{b}$ を用いて次式で表す。

$$
C_{B}=g n_{b}^{2} / h^{1 / 3}
$$

側壁においてもスリップ速度を考慮し摩擦係数 $C_{w}$ で せん断力を表現する.

\section{（2）差分化及び計算方法}

方程式の差分化及び計算方法は福岡らの方法と同様で ある.ここではその概要を述べるにとよ゙める. $s, n$ 軸 方向流速 $u, v$, 水位 $H$ 及び水深 $h$ の計算点を図一2に 示すように配置する. また橋脚表面では接線流速はゼ口 とし, 図一 2 に流速をゼロとする計算点を示す. 離散化 


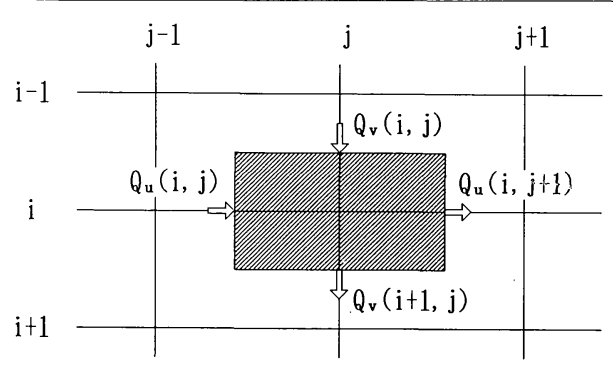

図一3·水深積分した流れの連続式の概念図

した運動方程式は風上差分により差分化すると，重み $l$ ごとに $u_{l}, v_{l}$ に関する一次式が得られ，これを計算点 ごとに解くことにより流れが求められる．連続式は河床 から水面まで積分し図一3に示すように差分化する。こ れを全ての計算点について連立し解くことにより水位が 求まる.ここで用いる差分式の安定性は, 文献 ${ }^{81,11), 12)}$ 確かめられている.

\section{4. 橋脚周辺の河床変動計算}

\section{（1）河床変動の基礎方程式}

橋脚周辺では乱れによる浮遊砂が活発に生じる.した がって, 橋脚周辺の河床変動計算には掃流砂と浮遊砂を 考慮した次の流砂の連続式を用いる.

$$
\frac{\partial z_{0}}{\partial t}+\frac{1}{1-\lambda}\left\{\frac{\partial q_{B s}}{\partial s}+\frac{1}{r} \frac{\partial\left(r q_{B n}\right)}{\partial n}+q_{s u}-w_{f} c_{b}\right\}=0
$$

ここに, $z_{0}$ は河床高, $t$ は時間, $\lambda$ は河床材料の空隙率, $q_{B s}, q_{B n}$ は $s, n$ 軸方向掃流砂量, $q_{s u}$ は河床からの砂の 浮上量, $c_{b}$ は河床付近の浮遊砂濃度, $w_{f}$ は浮遊砂の沈 降速度で Rubey の式より求める.

橋脚の周囲では掃流砂は非平衡運動状態を呈する．こ れを表現するため次の非平衡掃流砂運動の式 ${ }^{13)}$ 導入す る。

$$
\begin{aligned}
& \frac{\partial q_{B s}}{\partial s} \frac{q_{B s}}{\left(q_{B s}{ }^{2}+{q_{B n}}^{2}\right)^{1 / 2}}+\frac{\partial q_{B s}}{\partial n} \frac{q_{B n}}{\left(q_{B s}{ }^{2}+q_{B n}{ }^{2}\right)^{1 / 2}} \\
& \quad+\frac{q_{B s} q_{B n}}{r\left(q_{B s}{ }^{2}+q_{B n}{ }^{2}\right)^{1 / 2}} \\
& =\kappa_{B}\left(q_{B e s}-q_{B s}\right)+\frac{\tau_{c} \cos \theta}{\rho_{s} u_{d}}\left(\cos \overline{\gamma^{\prime}}-\cos \bar{\gamma}\right)
\end{aligned}
$$

$$
\begin{gathered}
\frac{\partial q_{B n}}{\partial s} \frac{q_{B s}}{\left(q_{B s}^{2}+q_{B n}^{2}\right)^{1 / 2}}+\frac{\partial q_{B n}}{\partial n} \frac{q_{B n}}{\left(q_{B n}{ }^{2}+q_{B s}{ }^{2}\right)^{1 / 2}} \\
-\frac{q_{B s}{ }^{2}}{r\left(q_{B s}{ }^{2}+q_{B n}{ }^{2}\right)^{1 / 2}} \\
=\kappa_{B}\left(q_{B e n}-q_{B n}\right)+\frac{\tau_{c} \cos \theta}{\rho_{s} u_{d}}\left(\sin \overline{\gamma^{\prime}}-\sin \bar{\gamma}\right) .
\end{gathered}
$$

ここに, $q_{B e s}, q_{B e n}$ は $s, n$ 軸方向の平衡状態での掃流 砂量, $\theta$ は河床面の最大勾配, $\tau_{c}$ は限界掃流力, $\rho_{s}$ は砂 の密度, $u_{d}$ は砂の移動速度で $8.5\left(u_{*}-u_{* c}\right), \overline{r^{\prime}}$ は外力 ベクトル（流れによるせん断力十河床面の傾きに伴うせ
ん断力）の向き， $\bar{\gamma}$ は流砂運動の向き， $\kappa_{B}$ は非平衡性を 規定するパラメータで次式(1)で与える.

$$
\kappa_{B}=5 \times 10^{-6}\left[\left\{\frac{\rho_{0} \nu^{2}}{\left(\rho_{s}-\rho_{0}\right) g}\right\}^{1 / 3} \tau_{*}\right]^{-1}
$$

橋脚の周囲では局所洗掘のため, 縦・横断勾配が大き くなる，このため, 平衡掃流砂量式には, 河床の縦横断 勾配の影響を取り込んだ次式 ${ }^{13)}$ をいる.

$$
\left.\begin{array}{c}
q_{B e} /\left(s g d^{3}\right)^{1 / 2}=K \tau_{*}{ }^{\prime}\left(\tau_{*}{ }^{\prime}-\tau_{* c}{ }^{\prime}\right) \\
q_{B e s}=q_{B e} \frac{\tau_{* s}{ }^{\prime}}{\tau_{*}{ }^{\prime}} \\
q_{B e n}=q_{B e} \frac{\tau_{* n}{ }^{\prime}}{\tau_{*}{ }^{\prime}} \\
\tau_{*}{ }^{\prime}=\left(\tau_{* s}{ }^{\prime 2}+\tau_{* n}{ }^{2}\right)^{1 / 2} \\
\tau_{* s}{ }^{\prime}=\tau_{* s}+\tau_{* c o} \sin \theta_{s} / \mu_{s} \\
\tau_{* n}{ }^{\prime}=\tau_{* n}+\tau_{* c o} \sin \theta_{n} / \mu_{s} \\
\tau_{* c}{ }^{\prime}=\tau_{* c o}\left[1-\left(\sin { }^{2} \theta_{s}+\sin ^{2} \theta_{n}\right)\right]^{1 / 2}
\end{array}\right\} \ldots .
$$$$
\text { ここに, } s \text { は砂の水中比重, } d \text { は河床材料の粒径, }
$$
$\tau_{* c o}$ は水平床上の無次元限界掃流力, $\tau_{* s}, \tau_{* n}$ は $s, n$ 軸方向の無次元掃流力, $\mu_{s}$ は静止摩擦係数, $K$ は定数,

浮遊砂濃度に関しては次の浮遊砂の連続式より求め る。

ここに， $c$ は浮遊砂濃度， $D_{s}, D_{n}$ および $D_{z}$ は，それ ぞれ $s, n$ 軸，および $z$ 軸方向の拡散係数であり，ここ では流れの計算に用いた渦動粘性係数 $\varepsilon$ を用いる.

\section{（2）浮遊砂の連続式の離散化}

浮遊砂の連続式を解く場合には，浮遊砂濃度の鉛直分 布を式（15）で表す。

$$
c(s, n, z)=\sum_{i=0}^{4} c_{i}(s, n) \cos i \pi z^{\prime}
$$

式（15）を式（14）に代入し，ガラーキン法により方 程式の離散化を行う. 重み関数は $\cos l \pi z^{\prime}(l=0,1,2$, $3,4)$ であり，水深積分すれば，重み $l$ ごとに次の方程 式が得られる。

$$
\begin{aligned}
& \left(\frac{\partial h c_{0} u_{0}}{\partial s}+\frac{\partial h r c_{0} v_{0}}{r \partial n}\right) \int_{0}^{1} \cos l \pi z^{\prime} d z^{\prime} \\
& \quad+\left(\frac{\partial h c_{0} u_{i}}{\partial s}+\frac{\partial h c_{i} u_{0}}{\partial s}+\frac{\partial h r c_{0} v_{i}}{r \partial n}+\frac{\partial h r c_{i} v_{0}}{r \partial n}\right) \\
& \quad \times \int_{0}^{1} \cos i \pi z^{\prime} \cos l \pi z^{\prime} d z^{\prime}+\left(\frac{\partial h c_{i} u_{j}}{\partial s}+\frac{\partial h r c_{i} v_{j}}{r \partial n}\right) \\
& \quad \times \int_{0}^{1} \cos i \pi z^{\prime} \cos j \pi z^{\prime} \cos l \pi z^{\prime} d z^{\prime}
\end{aligned}
$$




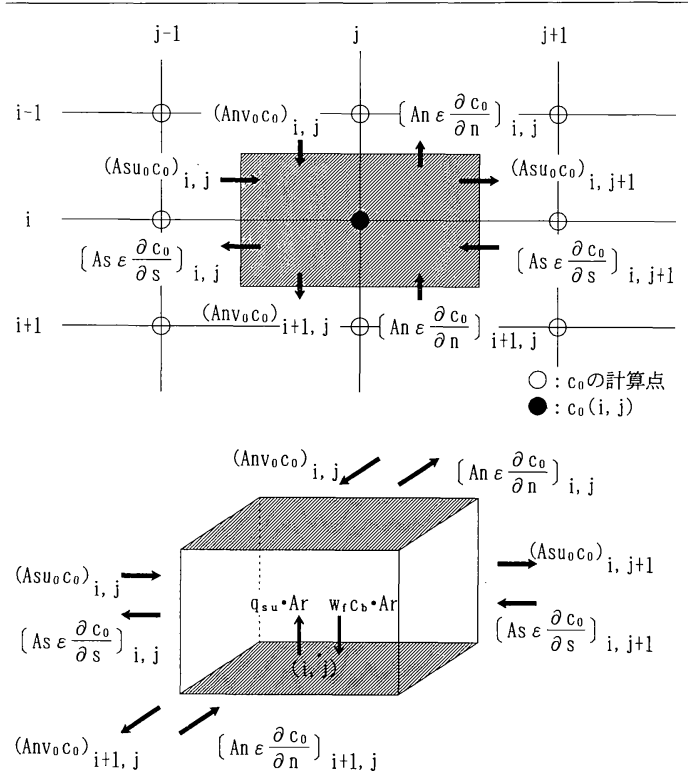

図一4 水深平均值を用いた浮遊砂連続式の模式図

$$
\begin{aligned}
& +l \pi c_{0} w_{i} \int_{0}^{1} \sin i \pi z^{\prime} \sin l \pi z^{\prime} d z^{\prime} \\
& +l \pi c_{i} w_{j} \int_{0}^{1} \cos i \pi z^{\prime} \sin j \pi z^{\prime} \sin l \pi z^{\prime} d z^{\prime} \\
& =\left[\frac{\partial}{\partial s}\left(h \varepsilon \frac{\partial c_{0}}{\partial s}\right)+\frac{\partial}{r \partial n}\left(h \varepsilon r \frac{\partial c_{0}}{\partial n}\right)\right] \int_{0}^{1} \cos l \pi z^{\prime} d z^{\prime} \\
& +\left[\frac{\partial}{\partial s}\left(h \varepsilon \frac{\partial c_{i}}{\partial s}\right)+\frac{\partial}{r \partial n}\left(h \varepsilon r \frac{\partial c_{i}}{\partial n}\right)\right] \\
& +\int_{0}^{1} \cos i \pi z^{\prime} \cos l \pi z^{\prime} d z^{\prime} \\
& +q_{s u}-w_{f} c_{b}-\frac{l^{2} \pi^{2} \varepsilon c_{i}}{h} \int_{0}^{1} \cos i \pi z^{\prime} \cos l \pi z^{\prime} d z^{\prime} \\
& +l \pi w_{f} c_{0} \int_{0}^{1} \sin l \pi z^{\prime} d z^{\prime} \\
& +l \pi w_{f} c_{i} \int_{0}^{1} \cos i \pi z^{\prime} \sin l \pi z^{\prime} d z^{\prime}
\end{aligned}
$$

ここに河床からの砂の浮上量 $q_{s u}$ にはいろいろな表現式 があるが，ここでは簡単のため次式で与える.

$$
q_{s u}=\alpha \times w_{f}\left(\frac{u_{*}}{w_{f}}\right)^{3}
$$

ここに $\alpha$ は, 流れの条件に応じて決まる係数である.

境界条件は，水面では水表面を横切って砂粒子が運ば れないという条件により規定し, 河床では砂の浮上量を 計算で求め与える.

\section{（3）差分化及び計算方法}

浮遊砂濃度の計算では計算点を格子点上に配置し, 連 続式の差分化は図一4の斜線で示す領域での収支を表す 形により行う. 図中の $A s, A n$ は $s, n$ 軸方向の側面積, $A r$ は底面積である. 重み $l$ 方程式の差分式を整理す ると $c_{l}$ に関する一次式が得られ全ての計算点において

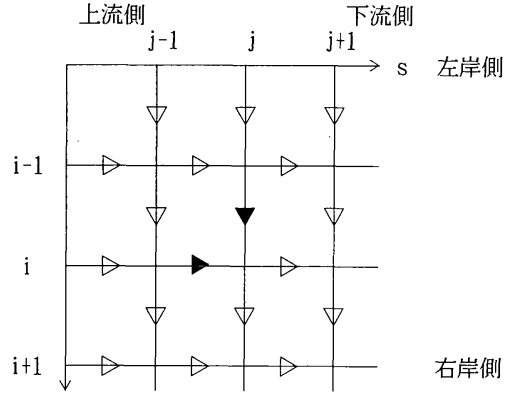

n

$$
\begin{aligned}
& \nabla: \mathrm{q}_{\mathrm{Bs}} \text { の計算点 } \quad \nabla: \mathrm{q}_{\mathrm{Bs}}(\mathrm{i}, \mathrm{j}) \\
& \nabla: \mathrm{q}_{\mathrm{Bn}} \text { の計算点 } \quad \nabla: \mathrm{q}_{\mathrm{Bn}}(\mathrm{i}, \mathrm{j})
\end{aligned}
$$

図一5 掃流砂量の計算点位置図

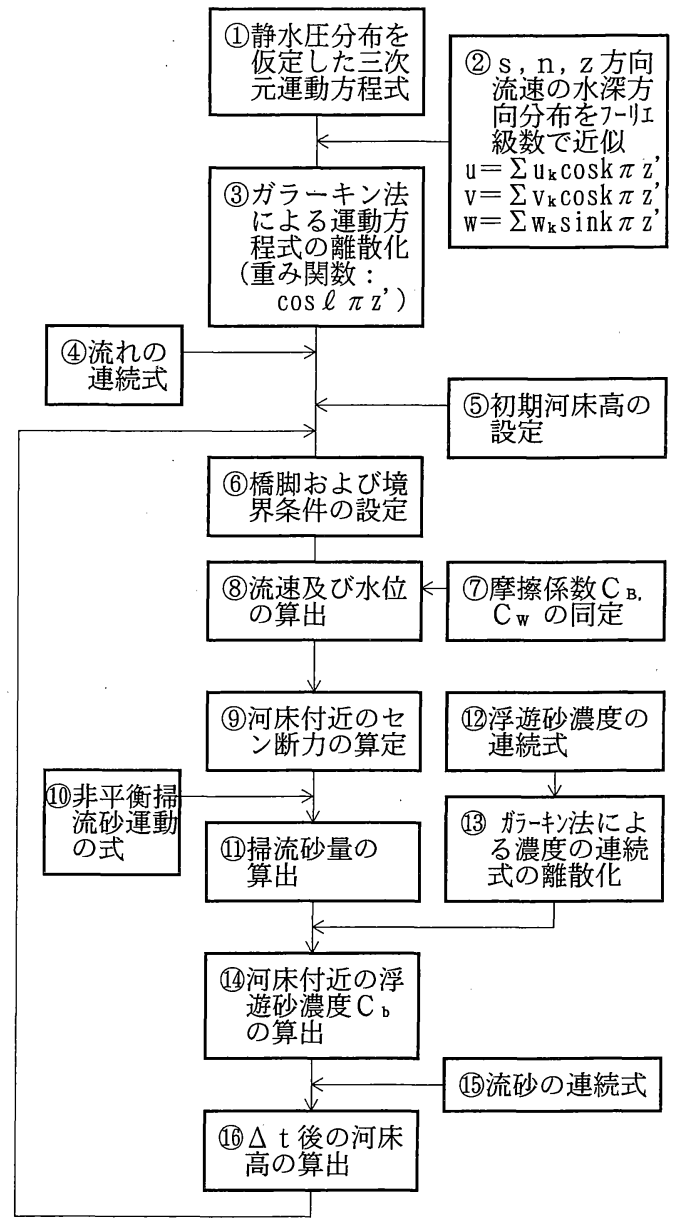

図一6 橋脚が設置された河道の流れと河床変動の計算フロー

連立して解くことにより, 浮遊砂濃度 $c_{l}$ が求められる. 境界条件は上流端では式 (17) から求められる浮上量 $q_{s u}$ を $q_{s u}=w_{f} \times c_{b}$ とおき, 河床近傍の濃度 $c_{b}$ をもとに 指数型の濃度分布により平均濃度を与える.下流端では 濃度勾配が一定の条件を与える. 計算領域内の河床では 
表一1 実験条件

\begin{tabular}{|c|c|}
\hline $\begin{array}{lll}\text { 橋 } & \text { 脚 } & \text { 幅 } \\
\end{array}$ & $0.5 \mathrm{~m} \quad(7.0 \mathrm{~m})$ \\
\hline 脚 長 & $1.0 \mathrm{~m}$ \\
\hline 平 均 水 深 & $0.75 \mathrm{~m} \quad(10.5 \mathrm{~m})$ \\
\hline 量 & $3.25 \mathrm{~m}^{3} / \mathrm{s}$ \\
\hline 平 均 流 速 & $1.08 \mathrm{~m} / \mathrm{s}(4.0 \mathrm{~m} / \mathrm{s})$ \\
\hline フールド 数 & 0.4 \\
\hline 河床材料 & $0.2 \mathrm{~mm}$ \\
\hline 比重 & 2.65 \\
\hline 水 路 & $4 \mathrm{~m}$ \\
\hline 路 & $90 \mathrm{~m}$ \\
\hline 河 床 勾 配 & $1 / 2000$ \\
\hline 通 水 時 間 & 1 時間 \\
\hline
\end{tabular}

（注）（）内は実河川スケールに換算した值である。
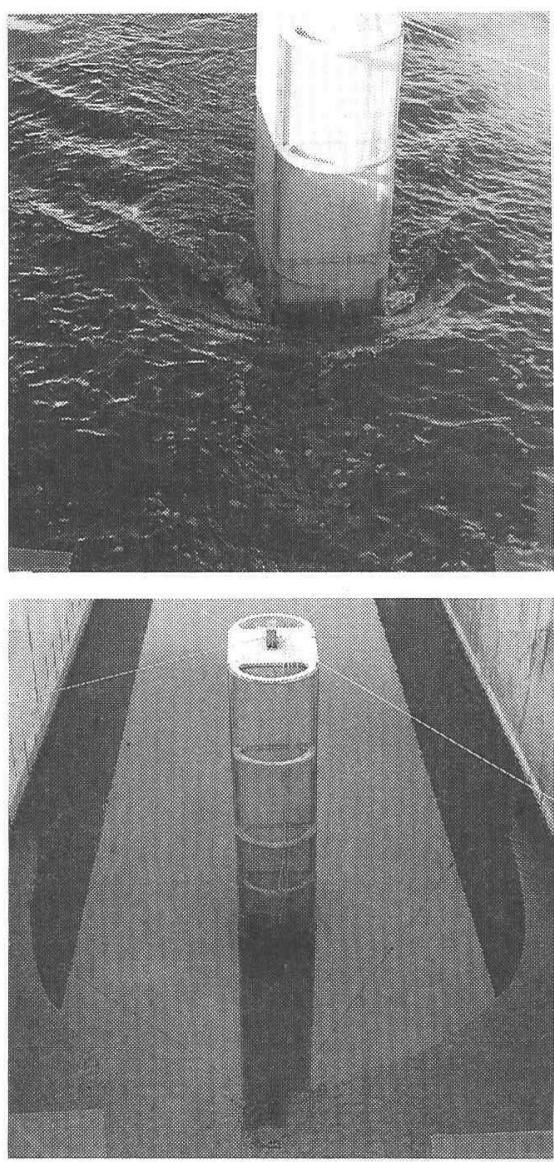

図一7通水時の流沉及び洗掘孔

式 (17) より求まる砂の浮上量を与える.

非平衡掃流砂量は, 図一 5 に示すように流速の計算点 と同じ点に流砂量の計算点を配置し，基礎式をそのまま 差分化する。差分式を整理す机は $q_{B S}, q_{B n}$ に関する一 次式が得られ，これを各計算点において解くことにより 非平衡掃流砂量が求めら扎る. 境界条件は上流端及び下 流端において平衡掃流砂量在与える.

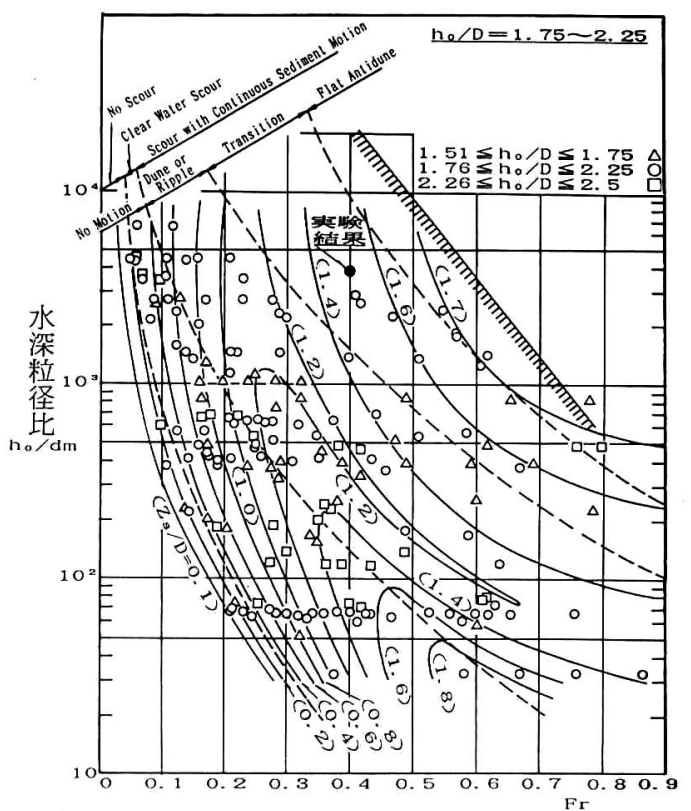

図一 8 洗拙深推測図 ${ }^{61}$

また河床高は, 河床勾配が砂の水中安息角 $\phi$ を満足 するよう平滑化を行う.

図一6に流れおよび河床変動計算のフローチャートを 示す，数値計算は，流れについては橋脚及び境界条件の 設定を行い奏測水面形を用いて摩擦係数 $C_{B}, C_{W}$ の同 定を行う。これらを用いて, 流速, 水位を繰り返し計算 により求める. 次いで計算で得られた流速, 水位を用い て河床付近のせん断力を算出し掃流砂量, 河床付近の浮 遊砂濃度を求め, 次の時問ステップの河床形状を求める. これを繰り返すことにより，橋脚が設定された河道での 安定な河床形状を求めることができる.

\section{5. 橋脚部抽出模型実験結果との比較}

模型実験は建設省土木研究所の幅 $4 \mathrm{~m}$, 長さ $90 \mathrm{~m} の$ 長方形直線水路のほぼ中央に幅 $0.5 \mathrm{~m}$, 長さ $1 \mathrm{~m}$ の半円 形小判型橋脚模型を設置し行われた。河床材料は平均粒 径 $0.2 \mathrm{~mm}$, 比重2.65のほほ均一な砂を河床勾配 $1 / 2000$ で教きならし, 流量 $3.25 \mathrm{~m}^{3} / \mathrm{s}$, 平均水深 0.75 $\mathrm{m}$ で 1 㭙問通水した. 実験は表一1に示すように大洪水 時の水理量に相当する条件で行っている. 通水終了後, 橋脚上流 $5 \mathrm{~m}$, 下流 $10 \mathrm{~m}$ の範囲について河床高の測定 在行った. 図一7は橋脚の上流側からみた通水時の流況 及び洗掘孔の広がりを示している. 最大洗掘深は $0.7 \mathrm{~m}$ で, $Z_{s} / D=1.4\left(Z_{s}\right.$ : 最大洗掘深, $D$ : 橋脚幅 $)$ である. 本実験は図一8に示す従来の土木研究所(i)実験条件上 比較す机ば, 図中に示すように, 同一フルード数におい て水深粒径比 $\left(h_{o} / d_{m}, h_{o}\right.$ : 平均水深, $d_{m}$ : 河床材料の 平均粒径) が大きく実際の砂河川の洪水時の現象に上り 
表一2 非平衡性の条件

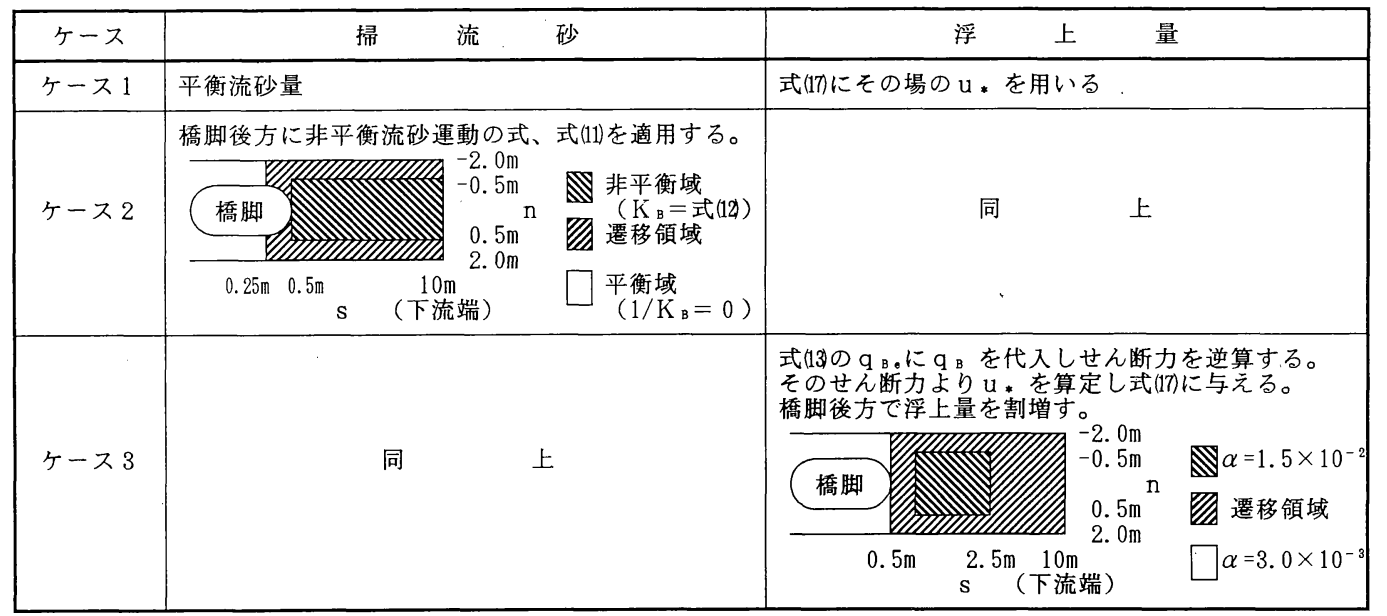

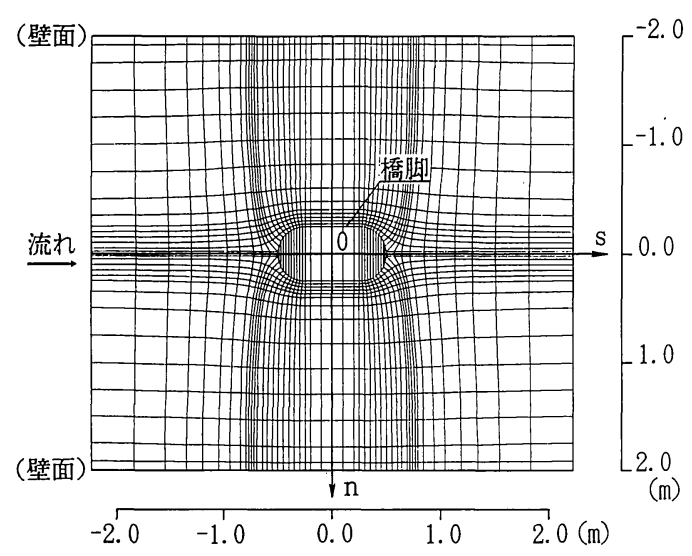

図一9 橋脚周辺のメッシュ分割図

近い条件で行われたものであることがわかる. 実験条件 より図一8に示す洗掘深推測図のパラメータは Fr= $0.4, h_{o} / d_{m}=3750, h_{o} / D=1.5$ である.これより $Z_{s} / D=1.4 \sim 1.5$ が求められ, 最大洗掘深の推定值は 0.7〜0.75 m となり, この值は実験結果にほぼ一致する. このことは, 土木研究所の最大洗掘深推定方法が実河川 に近い大きな水深粒径比 $\left(h_{o} / d_{m}\right)$ に対しても妥当な結 果を与えることを示すものである.

計算の対象区間は橋脚上流 $5 \mathrm{~m}$, 下流 $10 \mathrm{~m}$ の区間亡 した. 図一-9は, 橋脚周辺の計算メッシュ分割図である. 計算点は, 橋脚の前方及び後方については縦断方向に円 柱周りのポテンシャル流の流線に沿って配置し, その間 の側方は直線で結び小判型の橋脚形状を表現する配置と した. 曲率半径 $r$ は, 縦断方向に隣接する 3 点の平面座 標を用いて, 扇形の中心角之弦の長さを求算定してい る.

図一10は，水位及び河床高の計算結果と実験結果を 計算範囲全体にわたり水路中央, 右岸沿い断面について
縦断的に比較し，図一11 は橋脚周辺の河床高の比較を 河床コンタ一図により示している。ここに底面の粗度係 数 $N_{b}$ 側面の摩擦係数 $C_{w}$, 掃流砂量, 浮上量に関係す る係数 $K$ 亡 $\alpha$ には水位及び最大洗掘深の再現性から； $n_{b}=0.015, C_{W}=0.0005, K=20, \alpha=3.0 \times 10^{-3}$ を用 いた. ケース 1 は全領域が平衡掃流砂量式, 式 (13) で 計算した場合, ケース 2 は非平衡掃流砂運動の式を適用 した場合である。非平衡掃流砂運動の式は流れが剝離し 掃流砂の非平衡性が強いと考えられる橋脚背後に用い た。これは図一-9において，縦断的には $s=0.5 \mathrm{~m}$ より 下流側，横断的には $n=-0.5 \sim 0.5 \mathrm{~m}$ の範囲である. 一方, 平衡掃流砂量で表現できる区間は, 橋脚の側方よ り上流部（図一 9 の $s=0.25 \mathrm{~m}$ より上流部）とした．掃 流砂の平衡域加ら非平衡域への移行は, 式 (11) におい て $\kappa_{B}$ を大きくとれば (平衡掃流砂量) $=$ (非平衡掃流砂 量）となることから, 式 (12) より求められる $\kappa_{B}$ の值 を距離に応じてなめらかに変化させることにより設定す る.つまり, 平衡域で $1 / \kappa_{B}=0\left(\kappa_{B}=\infty\right)$ となり, 非平 衡域では式 (12) の值を用い $1 / \kappa_{B}$ 亡なるように変化さ せる.さらに横断方向にも，同様にして側壁で $\kappa_{B}$ が大 きく，水路中央部の非平衡域で式 (12) の值となる $\kappa_{B}$ の分布を設定し平衡掃流砂量の領域から非平衡掃流砂量 領域への移行を表現する．計算結果は橋脚前方から側方 の範囲については, 最大洗掘深の位置が側方にずれる形 で計算されるものの, 洗掘孔の広がる状況を概略表現し ている. 剝離流れとなる橋脚後方については, 実験結果 の洗掘域が広く後方まで広がるのに対して, 計算結果は 橋脚に比較的近い位置から堆積が始まっている。また ケース 2 とケース 1 を比較すれば洗掘域はやや広がって いるものの堆積域の高さは高くなっている.このような 計算結果と実験結果の差異は, 非平衡掃流砂運動を表現 する範囲が橋脚の直下流に限定され，その区間は洗掘さ 

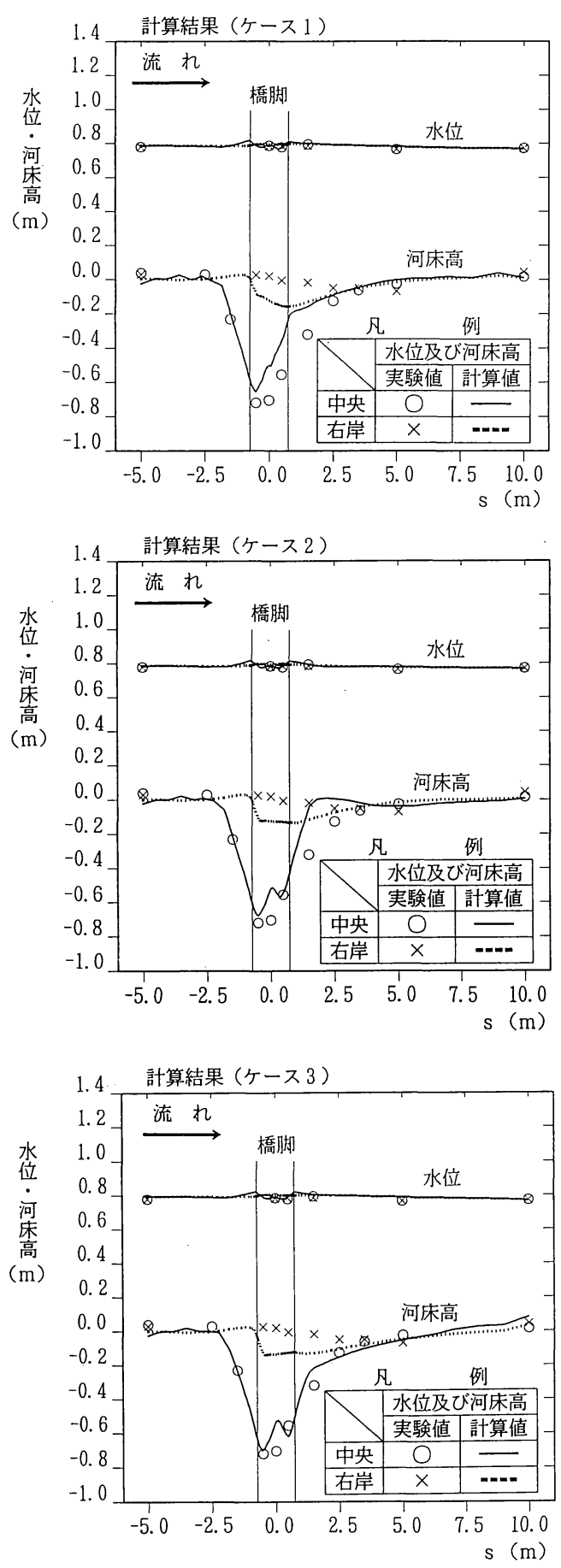

図一10 水位及び河床高縦断図

れるが，その下流側では洗掘されたものが堆積しやすく なるためと考えられる。これは橋脚後方での乱れによる 活発な浮遊砂現象を流砂の解析で十分取り込めていない

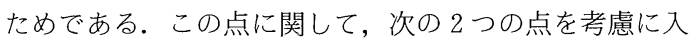
れて検討する.
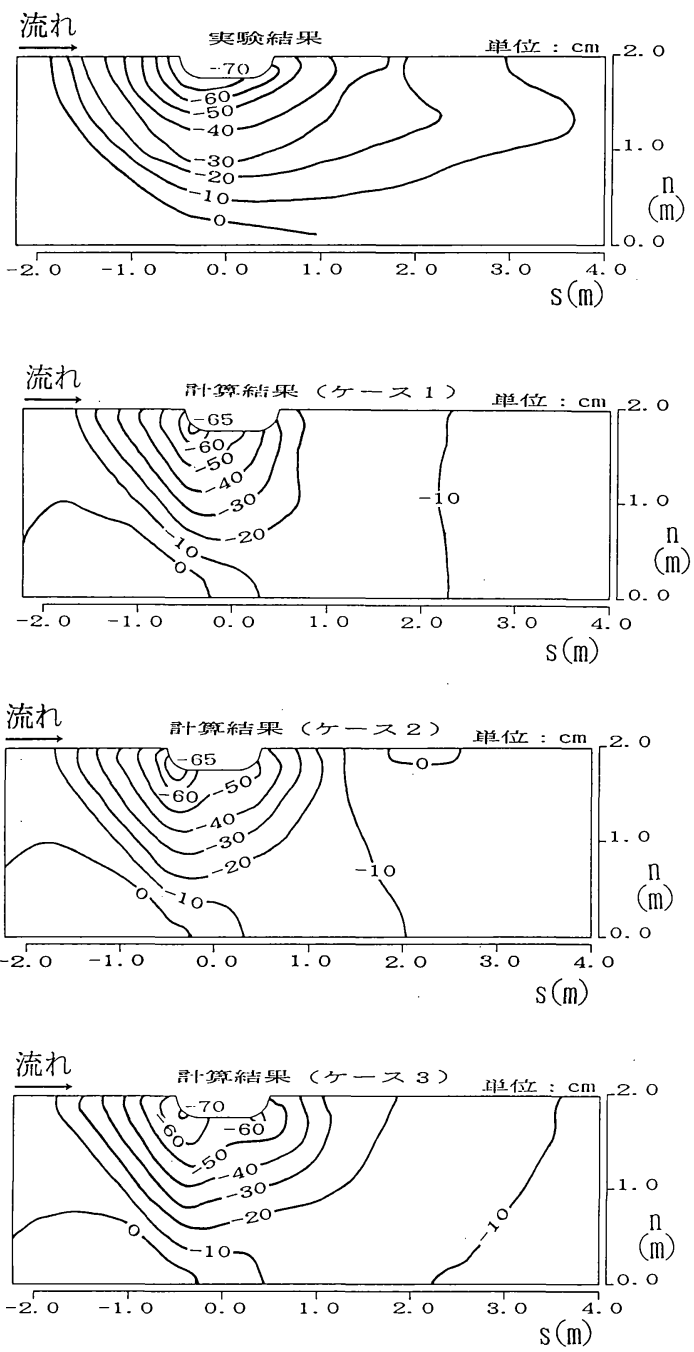

図一11 実験と計算の河床コンター比較図

第一に, 砂の浮上量を与える式 (17) に用いる摩擦速 度 $u *$ の評価に非平衡性の効果を取り込む. まず式(13) の平衡掃流砂量の表現式において $q_{B e}$ の代りにその場所 での掃流砂量 $q_{B}$ を用い, これよりせん断力を算定し $u_{*}$ を求める. 次にこのようにして計算した $u_{*}$ を用い, 浮 上量を算定する，第二は，活発に砂が巻き上がり浮遊砂 がより卓越する領域をモデルで十分考慮するために, 橋 脚後方で浮上量を増大させる.すなわち図一9において, 縦断的には橋脚直下流の $s=0.5 \mathrm{~m}$ から洗掘孔の下流端 $s=2.5 \mathrm{~m}$ の範囲, 横断的には $n=-0.5 \sim 0.5 \mathrm{~m}$ の範囲 で, 活発な砂の巻き上がりのため $\alpha=1.5 \times 10^{-2}$ を气え る. $s=0.5 \mathrm{~m}$ より上流側, 計算区間の下流端及び側壁 については先に述べたとおり $\alpha=3.0 \times 10^{-3}$ とし，その 間の区間では $\alpha$ を距離に応じて変化させる.このよう にして定めた定数を用いたモデルによる計算結果と実験 結果を水位・河床高縦断図及び河床コンタ一図により比 
較したものが図一10及び図一11のケース 3 である。洗 掘の状況は最大洗掘深, 洗掘孔の広がりについて, 計算 結果は実験結果を概ね表現できていると判断される.

本研究において対象とした解析の計算時間は，EWS (CPU：133 MHz，SPECfp $92: 112.5$ ) を用いて約 3 時間である.

\section{6. 結 論}

本研究では実河川に設置される橋脚を含む上・下流区 間の流れと河床変動を表現する数值計算モデルの開発を 目的として検討を行った.このモデルを用いた計算結果 と橋脚の局所洗掘についての大型水理模型実験結果を比 較し次の結論を得た。

（1）従来の橋脚模型実験に比較して，より実現象の 規模に近い条件で行われた大型水理模型実験によ る橋脚の最大洗掘深は, 従来の最大洗掘深推定式 でほぼ説明できる。

（2）橋脚まわりの局所洗掘現象を数值的に推定する ために，洗掘現象を規定する流砂運動を適切に考 慮したモデルと三次元の流れ場を近似的に説明で きるモデルを組み合わせ解くことによって，実用 的に十分な精度で局所洗掘を推定できるとの考え のもとに，橋脚のまわりの局所流と局所洗掘につ いての数值モデルの開発を行った.

橋脚背後の領域では，掃流砂の非平衡運動と河 床面から浮上する砂の非平衡分布を考慮し, 剝離 領域での流れの解析の不十分さを補うことによっ て, 実用的に十分な精度で大型水理模型実験によ る局所洗掘深, 範囲を説明する三次元数值シミュ レーション手法を得た。

謝辞：本研究を進めるに際し, 建設省関東地方建設局, 同利根川上流工事事務所, 同江戸川工事事務所，土木研 究所，(財）国土開発技術研究センタ一,（株）建設技術 研究所つくば試験部の関係各位より資料の提供等を頂い た.ここに記して感謝の意を表します.
参 考 文 献

1）土木学会：昭和 60 年度版水理公式集, p p. 272 276, 1985.

2）吉川秀夫: 流砂の水理学, 丸善, pp. 318 335, 1985.

3) Breusers, H. N. C., Nicollet, G. and Shen, H.W. : Local scour around cylindrical piers, J. of Hyd. Res., IAHR, 15， 3, pp. 211 252, 1977.

4）中川博次・鈴木幸一：橋脚による局所洗掘深の予測に関 する研究，京大防災研年報，第 17 号 B, pp. 725 751, 1974.

5）宇民 正：橋脚周辺の流れの機構と洗掘防止法に関する 研究, 京都大学学位論文, p. 184, 1975.

6）建設省土木研究所河川研究室：橋脚による局所洗掘深予 測之対策に関する水理的検討，土木研究所資料，第 1797 号, pp. 41〜 58, 1982.

7) Nils, R. B. Olsen and Morten, C. Melaaen: Threedimensional calculation of scour around cylinders, Journal of Hydraulic Engineering, ASCE, Vol.119, No. 9, pp. 1048 1054, 1993.

8）福岡捷二・渡辺明英・西村達也：水制工の配置法の研究, 土木学会論文集, No. 443, II-18, pp. 27〜36, 1992.

9）道上正規 - 檜谷 治：水制周辺の平面 2 次元河床変動計 算に関する研究, 水工学論文集, 第 36 巻, pp. $61 \sim 66$, 1992.

10）宮川朝浩 - 福岡捷二 - 富田邦裕 - 宇賀和夫 - 堀田哲夫 : 橋脚まわりの河床変動計算法の開発, 第 48 回年次学術講 演会講演概要集，第 2 部, pp. 940～941， 1993.

11）福岡捷二・高橋 晃・西村達也：信濃川小千谷・越路地 区の河床洗掘之堆積の軽減, 第 48 回年次学術講演会講演 概要集，第 2 部，pp. 124 125，1993.

12）西村達也・金尾健司・福岡捷二 : 河川合流部の洪水流之 河床変動, 第 48 回年次学術講演会講演概要集, 第 2 部, pp. 126 127, 1993.

13）福岡捷二・山坂昌成：直線流路の交互砂州, 第 27 回水理 講演会論文集, pp. 703 708, 1983.

14）金 舜範・福岡捷二・山坂昌成：流砂の非平衡性を規定 するパラメータ $\kappa_{B}$ の決定, 第 38 回年次学術講演会講演 概要集, 第 2 部, pp. 539〜540, 1983.

(1993.11.8 受付)

\section{PRACTICAL NUMERICAL SIMULATION OF LOCAL SCOUR AROUND A BRIDGE PIER}

\section{Shoji FUKUOKA, Kunihiro TOMITA, Tetsuo HOTTA and Tomohiro MIYAGAWA}

In order to evaluate the impact of bridge piers in a river on their downstream channel and hydraulic works, it is necessary to develop some effective numerical methods for estimating local scour as the supplement of the hydraulic model experiment. This study is intended to construct a three-dimensional numerical simulation model for the local scour around a bridge pier by improving Fukuoka's three-dimensional model in the computation of water flow and considering appropriately the non-equilibrium sediment transport in the calculation of bed variation. It is shown that the numerical simulation model can obtain, with adequate accuracy, solutions that are in good agreement with the experimental results of the local scour from the large-scale hydraulic model. 